\title{
A Long Time Coming
}

\author{
Dieter Grimm* (i)
}

(Received 03 July 2020; accepted 07 July 2020)

Keywords: Federal Constitutional Court; Court of Justice of the EU; European Central Bank; PSPP; Principle of Conferral

The commentary, especially from abroad, on the Federal Constitutional Court's judgment concerning the bond-buying programme undertaken by the European Central Bank (ECB) conveys the impression that something unimaginable has occurred. The German court has refused to follow the ruling of the Court of Justice of the European Union (CJEU), thereby setting "a bomb under the EU legal order." "Yet there is nothing new about the risk of conflict between the two courts. It came about when the Court of Justice of the European Union implicitly presumed, in $1963,{ }^{2}$ and explicitly declared, in $1964,{ }^{3}$ that European law takes precedence over domestic law, even over domestic constitutional law. This view was by no means without alternative, given that the Treaties of Rome do not address the precedence of Community law. The Member States involved in the dispute denied having agreed to any such precedence in the Treaties. Even the CJEU's Advocate General was unable to find any basis in the Treaties for the precedence of European law. ${ }^{4}$ The CJEU derived the precedence of European law from the purpose of the European Economic Community. ${ }^{5}$ It argued that there could be no common market if each Member State applied and interpreted European law however it saw fit.

This argument cannot be dismissed out of hand. This is why the Federal Constitutional Court has, in principle, recognised the precedence of Community law, and it was the first national apex court to do so. ${ }^{6}$ However, unlike the CJEU, the Federal Constitutional Court insists that Community law does not take precedence of its own accord but solely because the German legislator ordered its precedence of application in Germany in the Act Approving the Treaties. This may look like an academic discussion, but it has practical consequences. From the Federal Constitutional Court's perspective, the precedence of Community law only extends as far as the Federal Republic of Germany has actually conferred competences on the EU. ${ }^{7}$ European legal

${ }^{\star}$ Dieter Grimm was a Justice of the Federal Constitutional Court from 1987 to 1999. He was a member of the First Senate, which does not have jurisdiction over cases concerning core issues of European law.

${ }^{1}$ Martin Sandbu, German court has set a bomb under the EU legal order, FinANCIAL Times, May 5, 2020.

${ }^{2}$ ECJ, Case 26/62, NV Algemene Transport- en Expeditie Onderneming van Gend \& Loos v. Neth. Inland Revenue Admin., ECLI:EU:C:1963:1, Judgement of 5 Feb. 1963.

${ }^{3}$ ECJ, Case 6/64, Costa v. E.N.E.L., ECLI:EU:C:1964:66, Judgement of 15 July 1964.

${ }^{4}$ Opinion of Advocate General Lagrange, Case 6/64, Costa v. E.N.E.L. (June 25, 1964); Opinion of Advocate General Roemer, Case 26/62, Van Gend en Loos (Dec 12, 1962), 23.

${ }^{5}$ Costa, Case 6/64 at para. 10 .

${ }^{6}$ See Bundesverfassungsgericht [BVerfG] [Federal Constitutional Court] May 29, 1974, 37 EnTSCHEIDUNGEN DES BundesverfassungsGerICHTS [BVERFGE] 271, 278-279 [hereinafter Solange I]; Bundesverfassungsgericht [BVerfG] [Federal Constitutional Court] Oct. 22, 1986, 73 ENTSCHEIDUNGEN DEs BundesverfassungsGerichts [BVERFGE] 339, 375 [hereinafter Solange II].

${ }^{7}$ Bundesverfassungsgericht [BVerfG] [Federal Constitutional Court] June 30, 2009, 123 ENTSCHEIDUNGEN DES BUNDESVERFASSUNGSGERICHTS [BVERFGE] 267 [hereinafter Lisbon Judgement].

(c) The Author(s), 2020. Published by Cambridge University Press on behalf of the German Law Journal. This is an Open Access article, distributed under the terms of the Creative Commons Attribution licence (http://creativecommons.org/licenses/by/4.0/), which permits unrestricted re-use, distribution, and reproduction in any medium, provided the original work is properly cited. 
acts for which the EU is not competent are not binding. Whether Germany has conferred competences on the EU in a legally effective manner is governed by German constitutional law and can thus only be determined by the Federal Constitutional Court, not by the Court of Justice of the European Union.

The CJEU does not dispute that any legal act of the EU must be based on a competence that has been conferred on the EU in order to be legally effective. Yet based on its assumption that EU law has emancipated itself from, and now applies independently of, the will of the Member States, the CJEU insists that it is the only court with jurisdiction to assess whether a certain competence belongs to the EU and whether a legal act of the EU is covered by the competence in question. By contrast, the Federal Constitutional Court assumes that the power of review is shared. Under this assumption, the CJEU reviews whether legal acts of the EU are compatible with the Treaties and such decisions are binding on the entire EU; the Federal Constitutional Court reviews whether there has been a permissible conferral of competences on the EU in relation to Germany. If it comes to the conclusion that a legal act of the EU exceeds the EU's competences, the act may not be applied in Germany. ${ }^{8}$

The Federal Constitutional Court is by no means the only court to hold this view. Most constitutional courts of the Member States have followed it. Some even declared provisions of EU law to be inapplicable in their country before the Federal Constitutional Court did so. ${ }^{9}$ Thus, the Federal Constitutional Court's PSPP decision is not a novel phenomenon. It merely attracts more attention, firstly, because the decision was rendered by the German constitutional court, without any doubt the most powerful in the EU, and secondly, because it is a sensational case that entails a risk of considerable economic consequences. Perhaps it is also because the decision comes at a time of serious crisis requiring immense spending, even though the judgment has nothing to do with the coronavirus relief efforts and is expressly not aimed at them.

To assess the situation, we must look behind the scenes of the conflict that has now erupted. Why is the power of review so important to the Federal Constitutional Court? The usual answer is that it wants to retain its position of power, yet this is a premature conclusion that trivialises the underlying problem. For the Federal Constitutional Court, it is key that the European Union is a union of sovereign states, which make up its foundation, and that it must respect their identities, which are reflected primarily in their national constitutions. ${ }^{10}$ This special feature of the EU is safeguarded by the principle of conferral. ${ }^{11}$ According to this principle, only competences that have been conferred upon it by the Member States fall to the EU. It may not simply take away competences from the Member States at will. The same holds true for interpreting the Treaties: The EU may only interpret the competences conferred upon it; it may not create new ones.

Thus, the Federal Constitutional Court has acted entirely in accordance with the Treaties, which specifically provide for such a framework. The CJEU does not seek to dispute this either, and emphasises that it adheres to this framework in its decisions. However, the Federal Constitutional Court is not entirely certain that this is true. It finds that not only the Council, the Commission or the European Parliament can act in violation of the order of competences, but that such violations may also be committed by the guardian of the Treaties, the CJEU itself. This is indisputable in theory and does not have to mean that any such violations are necessarily deliberate. Yet in practice, too, the CJEU has fed this concern. Through its very extensive

\footnotetext{
${ }^{8}$ Bundesverfassungsgericht [BVerfG] [Federal Constitutional Court], Case No. 2 BvR 2661/06 (July 6, 2010), 126 ENTSCHEIDUNGEN DES BUNDESVERFASSUNGSGERICHTS [BVERFGE] 286, http://www.bverfg.de/e/rs20100706_2bvr266106en. html.

${ }^{9}$ See, e.g., Pl. ÚS 5/12 (Slovak Pensions) of 31 January 2012 of the Czech Constitutional Court, available at: http://www. usoud.cz/en/decisions/?tx_ttnews\%5Btt_news\%5D=37\&cHash=911a315c9c22ea1989d19a3a848724 e2; Court of Justice: Judgment of 19 April 2016, Case No. C-441/14, Dansk Industri (on behalf of Ajos A/S) v. Estate of Karsten Eigil Rasmussen [GC] (Den).

${ }^{10}$ Lisbon Judgement at para. 216 et seq.

${ }^{11}$ Treaty on European Union, Art. 5 (1) (2007).
} 
interpretation of the Treaties, the CJEU has eroded the principle of conferral - the basis of the entire European order - to a considerable extent and has caused deep rifts in the legal order of the Member States, for the most part in the interest of the four fundamental freedoms of the EU single market, and thus with a liberalising tendency. ${ }^{12}$

It is on this basis that the Federal Constitutional Court stated, in its Lisbon Judgment in 2009, that the EU's institutions, including its judicial institutions, "show a tendency of political selfenhancement". ${ }^{13}$ Since every time the EU usurps a competence, national constitutions become less significant, the Member States must prevent the EU from "decid[ing] on its own competence (Kompetenz-Kompetenz)" 14 or from violating the "constitutional identity" of the Member States. Since the CJEU itself has been a driving force behind the gradual erosion of the Member States' competences, only the domestic constitutional courts remain to act as a counterbalance. The Federal Constitutional Court has held that it must therefore retain the ability to safeguard the national constitutional identity and the order of competences set out in the Treaties. "In view of the progressing of European integration, there is no other way to safeguard the fundamental political and constitutional structures of sovereign Member States recognised by Art. 4(2) first sentence of the Treaty on European Union (Lisbon Treaty)."

However, the concerns expressed by the Karlsruhe court can only be fully grasped when considered in light of the EU's democracy problem. The EU derives its democratic legitimation primarily from the Member States, which are organised according to democratic principles and which, by way of the European Council and the Council of Ministers, play the central role in the system of European institutions. At the same time, the EU's own legitimation, derived from the election of the European Parliament, is relatively weak. On the one hand, this is because the European Parliament's powers lag behind those of the national parliaments; on the other hand, and primarily, it is because the turnout of EU citizens in European elections is low and the participation in such elections barely influences European policy. ${ }^{15}$ This is due to the fact that only national parties can be elected in European elections, yet these parties do not play an independent role in the European Parliament. Rather, work in the European Parliament is dominated by the European parliamentary groups, which do not stand for election, do not have roots in any European society and only determine their political platform once the elections have taken place.

The EU's democracy problem is compounded by a fact that is often overlooked: the EU's level of legitimation is compromised precisely by the influence the CJEU has created for itself by declaring the precedence of EU law. The EU has long ago gone beyond its initial purpose of creating an economic community and has become a political union, yet without the decision-making structures to match. The level of integration achieved is only partly the result of decisions of democratically legitimated and accountable institutions of the Member States and the EU; to a large extent, it is the result of decisions rendered by the CJEU. Within the EU, therefore, very significant political decisions are made in an unpolitical mode that excludes the participation of democratically legitimated and accountable institutions and of the public.

It is exactly this precedence of EU law that has ascribed to the Treaties the effect of a constitution. However, provisions stipulated at constitutional level are beyond the reach of the democratic process. They form the basis of political decisions, but are no longer subject to political decision-making. This is the purpose of constitutions, their raison d'être. It is just because of this effect that constitutions are limited to setting out several fundamental principles of the political and social order as well as determining the institutions of the community and their competences and procedures. Put differently, they set out how political decisions come about, but leave the

\footnotetext{
${ }^{12}$ E.g. Case C-438/05, Int'l Transp. Workers' Fed'n v. Viking Line ABP, 2007 E.C.R. I-10779 (2007).

${ }^{13}$ Lisbon Judgement, para. 237.

${ }^{14}$ Lisbon Judgement, para. 233.

${ }^{15} 2019$ European election results, EUROPEAN PARLIAMENT (Oct. 22, 2019), https://europarl.europa.eu/election-results-2019/ en/turnout/ (providing a chart comparing voter turnout since 2004).
} 
actual decision-making to the democratic process. The situation is different in the EU, given that the Treaties, unlike national constitutions, are full of provisions that would be mere statutory law in any Member State and would thus be open to democratic changes at any time.

Yet all of these policy provisions enshrined in the Treaties now also enjoy the precedence of application of the Treaties, and thus their quasi-constitutional effects. They are beyond the reach of the democratic process. In this context, elections have no consequences and the CJEU is able to operate freely. Within the scope of application of the Treaties, democratically legitimated and accountable institutions are not only unable to participate in decision-making, but also cannot change any decisions that have been made. This so-called constitutionalization of the Treaties, which were not conceived as a constitution, consequently leads to the depoliticization of the EU. Institutions that are directly or indirectly elected, and must therefore pay attention to public opinion, have no say in the policy areas governed by the Treaties. The Court of Justice, which does have a say, is unaffected by election results and public opinion. This way, European integration has silently been advanced, reaching a level that is not backed by an articulated democratic will. This is the EU's actual democracy problem, and it is linked precisely to the CJEU's case-law. ${ }^{16}$

It is hardly ever called into question that the Member States' potential for democratic legitimation is far greater than the EU's, not to mention the democratic legitimation of global supranational organisations. The EU's potential for democratic legitimation cannot be improved, as many have suggested, through institutional reform, in particular through the transformation of the EU into a parliamentary system modelled on state systems. Therefore, the EU will remain dependent on legitimation provided by the Member States for a long time to come. The EU cannot simply use the legitimation enjoyed by the Member States and redirect it to itself by further extending its powers. It should thus be in the EU's own interest to foster a strong democratic basis in the Member States, rather than continuing to undermine it. The principle of subsidiarity that was added to the Treaties in 1992 to prevent such undermining has not had any effect.

The discussion about the recent judgment of the Federal Constitutional Court disregards this context and therefore falls short. The narrow review competences that the Federal Constitutional Court reserves for itself vis-à-vis legal acts of the EU are based on important reasons; their necessity is confirmed by the strong judicial focus of European integration and its de-democratising effects. Nonetheless, it is a valid question whether the Federal Constitutional Court had to exercise its review competences, which it had affirmed time and again, particularly in relation to this subject matter and at just this time. The court did have other opportunities to voice its reservations, possibly in a manner that could have been more convincing and provoked less criticism, in particular in the OMT case (Draghi's announcement of "whatever it takes"). ${ }^{17}$

However, we have to look at the background in this instance, too. The OMT case was the first case in which the Federal Constitutional Court referred to the CJEU the question whether a legal act of the EU was based on a competence conferred by the Member States and had been undertaken in accordance with the Treaties. The CJEU had long been eager for a request for a preliminary ruling from Karlsruhe. When the Federal Constitutional Court made such a request, the much-vaunted "dialogue between the courts" could have begun. Yet on the part of the CJEU, there was relatively little willingness to engage in dialogue. Its response to the request from the Karlsruhe court does not appear to seriously address the Federal Constitutional Court's concerns. The CJEU told the Federal Constitutional Court, rather distantly, that its concerns were unfounded. ${ }^{18}$

The Federal Constitutional Court was not reassured by this response from Luxembourg. Still, it followed the CJEU, given that its decision at least indicated that the ECB did not operate in a legal

\footnotetext{
${ }^{16}$ See Dieter Grimm, The Constitution of European Democracy 89 et seq. (Justin Collings trans. 2017).

${ }^{17}$ Bundesverfassungsgericht [BVerfG] [Federal Constitutional Court], Case No. 2 BvR 2728/13, (Jan. 14, 2014), 134 BVERFGE 366, http://www.bverfg.de/e/rs20140114_2bvr272813en.html.

${ }^{18}$ ECJ, Case C-62/14, Gauweiler et al. v. Deutscher Bundestag, ECLI:EU:C:2015:400, Judgment of 16 June 2015.
} 
vacuum but had to respect legal boundaries. In the PSPP proceedings, the Federal Constitutional Court again made a fully reasoned reference to the CJEU and again, it cannot be said that the CJEU addressed it in a manner that is in keeping with the notion of dialogue. In any case, the CJEU's response could not dispel the Federal Constitutional Court's concerns. Rather, the Federal Constitutional Court concluded that the CJEU refrained from conducting effective oversight of the ECB and enabled the ECB to freely determine the extent and scope of its mandate. ${ }^{19}$

Nonetheless, in terms of substance, the Federal Constitutional Court showed restraint when objecting to the CJEU's conclusions and suggested possible solutions. It refrained from accusing the ECB of crossing the limit between monetary policy (which is part of its tasks) and economic policy (which is not), and thus chose not to strike a major blow. It did not find a manifest circumvention of the prohibition on crossing that limit. However, the Federal Constitutional Court assumed that the ECB exercised its competence without assessing the proportionality of its bond-buying programme, as required by Art. 5 of the Treaty on European Union. It gave the ECB the opportunity to conduct a proportionality assessment following its judgment and, depending on the outcome of that assessment, to either justify or adjust its actions. This does not call into question the ECB's independence. Critics often claim that the Federal Constitutional Court issued instructions to the ECB in its judgment, yet this is not true. The ECB is not subject to the Basic Law.

However, in relation to the CJEU, the Federal Constitutional Court's judgment is less moderate. The CJEU is accused of having acted ultra vires by rolling back the legal boundaries for the ECB to such an extent that the ECB was free to conduct economic policy and thus to encroach upon the competences of the Member States. The Federal Constitutional Court gives compelling reasons for this assessment in its judgment. It meticulously shows that, in relation to the ECB, the CJEU departed from its own standards for the application of the principle of proportionality. The way in which the Federal Constitutional Court chose to deliver this was even less moderate. No court would like to hear that its judgment was "simply not comprehensible" (schlechterdings nicht mehr nachvollziehbar) and thus "objectively arbitrary" (objektiv willkürlich). On the basis of its considerations, the Federal Constitutional Court then had to draw the following conclusion: "The CJEU Judgment itself constitutes an ultra vires act and thus has no binding effect [in Germany]."20

Once again, however, we have to look at the reasons for this conclusion. The Federal Constitutional Court has been caught in a trap that it set itself with the best, pro-European intentions. In an order from 2010, it elaborated on its intention, which it had expressed numerous times, to refuse to comply with a CJEU judgment only in extremely exceptional cases and thus set a very high hurdle for itself. The Federal Constitutional Court stated in that order that it would only make such a decision on three conditions: firstly, after obtaining the CJEU's legal opinion; secondly, mere disagreements concerning the correct interpretation of the Treaties would not be sufficient, rather, the CJEU's view would have to be simply untenable and thus arbitrary; thirdly, such a CJEU judgment would have to result in a structural shift of competences away from the Member States towards the EU. Following that declaration, the Federal Constitutional Court had no real alternative but to use this approach, which had been meant to protect the CJEU, against it.

Can this conflict be resolved? There are two answers: a general answer regarding the relationship of the two courts and a case-related answer regarding the consequences for the ECB's bondbuying programme. As far as general considerations are concerned, the law reaches its limits. Since both courts provide accurate reasoning based on their respective premises, no solution is in sight. There are two conflicting judgments in one and the same case at the same time; as the EU is no state with a set hierarchy, none of the two courts can overturn the other court's

\footnotetext{
${ }^{19}$ Bundesverfassungsgericht [BVerfG] [Federal Constitutional Court], Case No. 2 BvR 859/15, para. 127 (May 5, 2020), http://www.bverfg.de/e/rs20200505_2bvr085915en.html [hereinafter PSPP Judgement].

${ }^{20}$ PSPP Judgement, para. 119.
} 
judgment. Thus, it falls to politicians to decide how to handle this situation. Legal scholarship even sees positive aspects arising from it: the lack of any hierarchy forces the courts to be considerate of one another. Until 5 May 2020, the Federal Constitutional Court had shown such consideration, albeit sometimes less willingly. The CJEU has not honoured this. It would be beneficial to all if the courts were mutually considerate in the future.

As far as case-related considerations are concerned, it is sufficient that the ECB issue a declaration, in any form, setting out why its bond-buying programme satisfies the requirements arising from the principle of proportionality. The Bundesbank can then continue to participate in the programme. If the ECB were to issue such a declaration, the main adverse effect of the judgment would then lie in its encouraging effect on those EU Member States that keep drifting further away from the rule of law. This is pointed out by almost all critics, and there is hardly any doubt that Hungary and Poland will refer to the German judgment in their dispute with the Commission, even though the Federal Constitutional Court has strived to make it clear that its decision is an exception. Yet should we really ask of judges, who must decide according to the law, to refrain, upon a sober review, from making a decision they consider legally required, simply because others might abuse it?

Cite this article: Grimm D (2020). A Long Time Coming. German Law Journal 21, 944-949. https://doi.org/10.1017/ glj.2020.55 